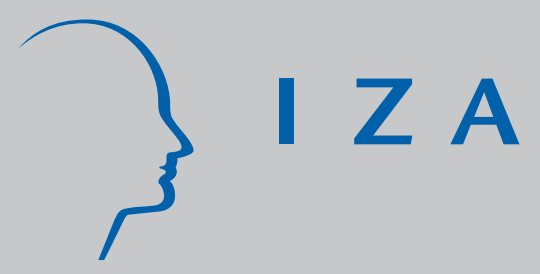

IZADP No. 2744

Defending Gibrat's Law as a Long-Run Regularity

Francesca Lotti

Enrico Santarelli

Marco Vivarelli

April 2007 


\title{
Defending Gibrat's Law as a Long-Run Regularity
}

\author{
Francesca Lotti \\ Bank of Italy \\ Enrico Santarelli \\ University of Bologna, Max Planck Institute of Economics Jena \\ and ENCORE Amsterdam \\ Marco Vivarelli \\ Università Cattolica del Sacro Cuore, CSGR Warwick, \\ Max Planck Institute of Economics Jena and IZA
}

Discussion Paper No. 2744
April 2007

IZA

P.O. Box 7240

53072 Bonn

Germany

Phone: $+49-228-3894-0$

Fax: +49-228-3894-180

E-mail: iza@iza.org

Any opinions expressed here are those of the author(s) and not those of the institute. Research disseminated by IZA may include views on policy, but the institute itself takes no institutional policy positions.

The Institute for the Study of Labor (IZA) in Bonn is a local and virtual international research center and a place of communication between science, politics and business. IZA is an independent nonprofit company supported by Deutsche Post World Net. The center is associated with the University of Bonn and offers a stimulating research environment through its research networks, research support, and visitors and doctoral programs. IZA engages in (i) original and internationally competitive research in all fields of labor economics, (ii) development of policy concepts, and (iii) dissemination of research results and concepts to the interested public.

IZA Discussion Papers often represent preliminary work and are circulated to encourage discussion. Citation of such a paper should account for its provisional character. A revised version may be available directly from the author. 
IZA Discussion Paper No. 2744

April 2007

\section{ABSTRACT}

\section{Defending Gibrat's Law as a Long-Run Regularity}

According to Gibrat's Law of Proportionate Effect, the growth rate of a given firm is independent of its size at the beginning of the period examined. While earlier studies tended to confirm the Law, more recent research generally rejects it. This paper reconciles these two streams of literature, taking into account the role of market selection and learning in reshaping a given population of firms through time. Consistently with previous studies, we found that Gibrat's Law has to be rejected ex ante, since smaller firms tend to grow faster than their larger counterparts. However, a significant convergence towards Gibrat-like behavior can be detected ex post. This finding is an indication that market selection "cleans" the original population of firms, so that the resulting industrial "core" does not depart from a Gibrat-like pattern of growth. From a theoretical point of view, this result is consistent with those models based on passive and active learning, and can be seen as a defense of the validity of the Law in the long-run.

JEL Classification: L11, L26

Keywords: Gibrat's Law, firm size, firm age, firm survival, firm growth

Corresponding author:

Marco Vivarelli

Facoltà di Economia

Università Cattolica

Via Emilia Parmense 84

I-29100 Piacenza

Italy

E-mail: marco.vivarelli@unicatt.it 


\section{Introduction}

As discussed in detail in Section 2, Gibrat's Law has been rejected by recent studies. Firms' growth does not appear to be independent of initial size; in fact, small and young firms have a higher growth rate than their larger and older counterparts. However, earlier studies, based on small subsamples of well-established, mature, large firms, tended to confirm the Law. This poses a puzzle.

One way to reconcile these two streams of literature is to test whether a given population of firms tends to converge to Gibrat-like behavior through time, the idea being that market selection with the correlated exit of the less efficient firms and the convergence to the minimum efficient scale (MES) of the most efficient ones - is able to bring about a "steady state" where a much more homogeneous population of firms behaves according to the Law of Proportionate Effect. In this context it may well be that Gibrat's Law can be rejected “ex ante” when considering the entire population of firms and the entire period examined and confirmed ex post within the sole population of surviving firms at the end of the period.

The innovative feature of this study is that it tests Gibrat's Law through time (i.e. year by year) allowing the selection of the initial population, while previous studies either investigated a subsample of large mature firms (ex post approach) or a given population of firms over a certain time period (ex ante approach). In the former approach the investigated firms are the outcome of a previous (not investigated) market selection and constitute the industrial "core” within which Gibrat's Law tends to be confirmed. In the latter approach - testing the Law over a period of time using a given, immutable population - the role of smaller firms, which has to grow fast in order to survive, is magnified and the Law is generally rejected. 
As far as we know, this paper is the first attempt to track an initial population of existing firms in a sector year by year, to see whether the overall rejection of Gibrat's Law over a given period of time may actually conceal a possible convergence in favor of the Law through time. If such is the case, earlier and recent seminal papers on the subject might be reconciled.

The paper is organized as follows: the next section expands the discussion of our hypothesis through an extensive survey of previous literature; Section 3 describes the data used and the empirical experiments; Section 4 presents the econometric results while Section 5 briefly concludes.

\section{Previous literature: Gibrat's Law as a theoretical and empirical crossroad}

The debate on Gibrat's Law of Proportionate Effect has been going on for some time (cf. Santarelli, Klomp and Thurik, 2006). A commonly-accepted interpretation of the Law originally "discovered” by Robert Gibrat (1931) is that the growth rate of a given firm is independent of its size at the beginning of the period examined. In other words, "the probability of a given proportionate change in size during a specified period is the same for all firms in a given industry - regardless of their size at the beginning of the period" (Mansfield, 1962, p. 1031). Until the 1970s, the Law was quite popular among both applied and theoretical industrial economists, basically for two reasons.

On the one hand, the stochastic properties of the Law were consistent with the prevailing dynamic patterns of development observable in most industrial sectors of the time. In particular, as Simon and Bonini (1958) pointed out, if one “...incorporates the Law of proportionate effect in the transition matrix of a stochastic process, [...] then the resulting steady-state distribution of the process will be a highly skewed distribution”. This is also the case nowadays, when most economic sectors are characterized by a log-normal size distribution with a bulk of small- and medium-sized firms and a few larger ones. The theoretical consistency between Gibrat's Law and the observed 
size distribution of firms across different industrial sectors has also been proposed by Steindl (1965) and treated through examples and simulations by Prais (1976, Chapter 2).

On the other hand, from a purely theoretical perspective, Gibrat's Law proved consistent (or at least not in contrast) with some by now classic economic models of the firm size distribution. For example, Robert Lucas put forward an important updating of Jacob Viner's original theory addressed to explain the size distribution of business firms. While Viner (1932) had seen business size distribution as the outcome of cost-minimizing firms (characterized by U-shaped long-run average cost functions and facing a given market demand), Lucas (1978) postulated size distribution as a solution to the problem of allocating productive factors over managers of different “talent", so as to maximize aggregate output. His model predicted the "full” size distribution of firms, conditioning it to a given distribution of the managerial talents; in fact, in his view, firms were collections of assets whose matching to managers can change arbitrarily from period to period. As stated by Lucas himself, this modern "organizational” theory of the firm was not in contrast with the “....independence of firm growth and size: Gibrat's Law, or the Law of proportionate effect” (ibidem, p. 514); therefore he devoted the fifth section of his seminal article to the special case which satisfied the Law.

However, its theoretical popularity notwithstanding, empirical tests of the Law were highly controversial. While earlier studies based on subsamples of large and mature firms had tended to confirm the Law (Hart and Prais, 1956; Simon and Bonini, 1958; Hymer and Pashigian, 1962), further research began to challenge its overall validity. In his seminal work, Mansfield (1962) investigated U.S. steel, petroleum and tires sectors in different time periods and found that Gibrat's Law was failing in the majority of cases, with smaller firms growing faster than their larger counterparts. This outcome was largely confirmed by many subsequent empirical studies using more comprehensive specifications (including firm's age and other controlling regressors) and more sophisticated econometric techniques able to take into account both sample selection and 
heteroskedasticity problems ${ }^{1}$ (Hall, 1987; Evans, 1987a and 1987b; Dunne, Roberts and Samuelson, 1989; Dunne and Hughes, 1994; Hart and Oulton, 1996; Audretsch, Santarelli and Vivarelli, 1999; Calvo, 2006). In the meantime, other studies managed to generate feasible features in sectoral concentration, lognormality in business size distribution and adequate representations of the entry and exit dynamics, using models where the basic Gibrat process was heavily modified in order to capture the departures from the Law found by the empirical research (Cabral, 1995; McCloughan, 1995).

This new evidence in contrast with the Law was quite challenging from a purely theoretical point of view. The first author who took up this challenge seriously was Boyan Jovanovic, with his well-known and important contribution published in Econometrica (1982) ${ }^{2}$. The author proposed a Bayesian model of noisy selection, according to which efficient firms grow and survive, whereas inefficient firms decline and fail. In particular, in Jovanovic's model of passive learning firms are initially endowed with unknown, time-invariant characteristics, i.e. ex-ante efficiency parameters, while ex-post the prior distribution is updated as evidence comes in which leads some firms to discover that they are more efficient than others. Thus, each firm has to decide on its strategy: whether to exit, to continue at the same size, to expand, or to reduce its productive capacity. This model appears to be consistent with the empirical rejection of Gibrat's Law in the short run (ibidem, 1982; figure 1, p. 650), when efficient surviving smaller firms accelerate their growth in comparison with their larger and more experienced counterparts. However, there is no reason - in Jovanovic's model - to deny the Law in the very long run, when noisy selection has been completed and a steady state is reached by the economy.

The same line of argument applies to more recent models of active learning. Richard Ericson and Ariel Pakes (1995) assume that all the decisions taken by firms are meant to maximize the expected discounted value of the future net cash flow, conditional on the current information set. In their model, a firm knows its own characteristics and those of its competitors, along with the 
future distribution of industry structure, conditional on the current structure. Jovanovic's assumptions concerning small industry size and product homogeneity are relaxed, and new entries may either adjust their size to the minimum efficiency scale (MES) level of output of the "core" of the industry, or choose/find a niche within which the likelihood of survival is relatively high even though the firm does not grow fast. In a subsequent work, Pakes and Ericson (1998) examine two cohorts of firms from Wisconsin in the retail and the manufacturing industries, and find that the structure of the former industry is compatible with Jovanovic's passive learning model, while that of the latter is compatible with their model of active exploration. In both models optimal behavior generates a set of stopping states which can imply exit from the market. These Markow Perfect Nash equilibria appear consistent with the violation of Gibrat's Law in the short run, and with the validation of the Law in the very long run (cf. also Lotti and Santarelli, 2004).

Bearing the theoretical and empirical models discussed above in mind, in the late 1990s scholars put forward the hypothesis that "Gibrat's Legacy" (Sutton, 1997; Caves, 1998) was defendable not as a general Law, but only as a dynamic rule valid for large and mature firms that had already attained the MES level of output, but not for smaller (younger) ones operating at a suboptimal scale (Geroski, 1995).

The purpose of this paper is indeed to reconcile earlier literature with more recent research, showing that the rejection of Gibrat's Law ex ante can be coupled with the defense of the Law ex post, as a long-run regularity. We will try to test this hypothesis through an empirical experiment where the same population of firms is tracked over time on a yearly base. The basic hypothesis is that Gibrat's Law should be rejected ex ante and over the entire time period, but validated ex post when noisy (Jovanovic) or active (Ericson and Pakes) selection has played its evolutionary role in reshaping the original population. In fact, repeating the test of Gibrat's Law year by year enables us to consider what happens when the original heterogeneous population of existing firms is gradually 
reshaped in favor of the most efficient ones, i.e. to set up an empirical counterpart of the learning and selection processes put forward by the theoretical models described above.

While previous recent literature has found that Gibrat's Law must be rejected over a given period of time, since smaller firms tend to grow faster than their larger counterparts, no previous study has attempted to determine whether this result is robust once selection and learning through time are fully taken into account ${ }^{3}$.

\section{Data and methodology}

In this paper we deal with the Italian radio, TV \& communication equipment (ISIC 3832) industry ${ }^{4}$ from 1987 to 1994, including all the firms which were active in the sector at the beginning of the period. More specifically, we use a unique data set from the Italian National Institute for Social Security (INPS). This data set identifies all existing firms with at least one paid employee in the examined sector and tracks their employment performance - our measure of size - at yearly intervals from January 1987 to January $1994 .^{5}$ The original INPS file was checked in order to identify entry and failure times correctly and to detect inconsistencies in individual tracks due to administrative factors, and cancellations due to firm transfers, mergers and takeovers. This cleaning procedure reduced the total number of firms in the database to 3,285.

The rationale behind the decision to choose this industry is twofold. First, it has long been recognized as the core of 'electronics', a crucial sector as far as new technologies are concerned (cf. Carree, 2002). Second, at the beginning of the period examined it was a rather outdated sector in Italy, still lagging behind the technological revolution brought about by the passage from analog to digital signals. Thus, between the late 1980s and early 1990s it experienced a significant “shakeout” (as defined by Klepper and Miller, 1995), which - as has been the case in several 
countries - accompanied its shift to the group of top technology-intensive industries (cf. Martins et al., $1996^{6}$ ). Indeed, as can be seen in Table 1, the examined population exhibited a remarkable rate of failure (more than $40 \%$ over seven years) as a consequence of the severe technological and market shakeout experienced by the sector ${ }^{7}$. In this respect, in the period under examination the Italian radio, TV \& communication equipment industry can be regarded as an adequate example of a sector characterized by learning and selection as described by the theoretical models discussed above $^{8}$.

\section{- Insert table 1 here -}

Using the existing firms in the sector at January 1987, and according to the general hypotheses proposed above, Gibrat's Law will be tested both over the entire period (1987-1994) and year by year. This set of estimates will enable us to answer the following two questions:

H1) Is Gibrat's Law valid over the entire period (ex ante hypothesis)?

H2) Is there any convergence towards a Gibrat-like pattern of growth through time (ex post hypothesis)?

If both these hypotheses were confirmed, the puzzling debate about the validity of Gibrat's Law might be recomposed: although the Law can be rejected when considering the overall evolution of an ex ante population of existing firms, it may nevertheless be an accurate description of the patterns of growth of the well-established firms belonging to that ex post sub-population which results from market selection and learning processes.

The central relationship tested in this study is the logarithmic specification of Gibrat's Law:

$$
\ln S_{i, t}=\beta_{0}+\gamma_{1} \ln S_{i, t-1}+\varepsilon_{i, t}
$$


where $\mathrm{S}_{\mathrm{i}, \mathrm{t}}$ is the size of firm $i$ at time $\mathrm{t}, \mathrm{S}_{\mathrm{i}, \mathrm{t}-1}$ is the size of the same firm in the previous period and $\varepsilon_{\mathrm{i}, \mathrm{t}}$ is a random variable distributed independently of $\mathrm{S}_{\mathrm{i}, \mathrm{t}-1}$. Following Chesher (1979, p.404), if both sides of equation (1) are exponentiated, it becomes clear that if $\gamma_{1}$ is equal to unity, then growth rate and initial size are independently distributed ${ }^{9}$ and Gibrat's Law is in operation. By contrast, if $\gamma_{1}<1$, smaller firms grow at a systematically higher rate than do their larger counterparts, while the opposite is the case if $\gamma_{1}>1$. For estimation purposes and to make the interpretation of the results easier, the model is parameterized as follows:

$$
\ln S_{i, t}-\ln S_{i, t-1}=\beta_{0}+\left(\gamma_{1}-1\right) \ln S_{i, t-1}+\varepsilon_{i, t}
$$

where the new coefficient $\beta_{1}$ is defined as $\beta_{1}=\left(\gamma_{1}-1\right)$, so that one can test the validity of the Law with the significance of parameter $\beta_{1}$ (as before, if $\beta_{1}=0$ Gibrat's Law holds; if $\beta_{1}<0$ smaller firms grow at a higher rate than their larger counterparts, while the opposite is the case if $\beta_{1}>0$ ). Let $\chi_{\mathrm{i}, \mathrm{t}}$ be an indicator function which takes value 1 if firm $i$ is still alive at time $t$ and 0 otherwise. Accordingly, observed data on firm size can give only the conditional expectation of the difference $\Delta \ln S_{\mathrm{i}, \mathrm{t}}=\ln \mathrm{S}_{\mathrm{i}, \mathrm{t}}-\ln \mathrm{S}_{\mathrm{i}, \mathrm{t}-1}$, given $\mathrm{S}_{\mathrm{i}, \mathrm{t}-1}$ and $\chi_{\mathrm{i}, \mathrm{t}}=1$; i.e., according to our specification:

$$
E\left(\Delta \ln S_{i, t} \mid S_{i, t-1}, \chi_{i, t}=1\right)=\beta_{0}+\beta_{1} \ln S_{i, t-1}+E\left(\varepsilon_{i, t} \mid S_{i, t-1}, \chi_{i, t}=1\right)
$$

If the conditional expectation of $\varepsilon_{t}$ is zero, the regression function for the selected subsample is the same as the population regression function, the only drawback being a loss of efficiency due to the smaller number of observations available. However, if this is not true, the last term of equation (3) needs to be included in the regression function. It is for this reason that a rule for $\chi_{t}$ is required, and the most natural way to deal with this kind of selection is to use a survival 
equation, i.e. a probit model, given that we can detect exactly when a firm exits the market. In a more general formulation, this is the same as saying that:

$$
\begin{cases}\operatorname{Prob}\left(\chi_{i}=1\right)= & \text { Probit Selection Equation } \\ \Phi\left(\alpha^{\prime} z_{i}\right) & \\ & \text { observed only if } \chi_{\mathrm{i}}=1\end{cases}
$$

If we denote the residual of equation (4a) with $\mu_{i, t}$ and if we assume that the error terms are normal, respectively $\varepsilon_{i} \sim N\left(0, \sigma_{\varepsilon}\right)$ and $\mu_{i} \sim N\left(0, \sigma_{\mu}\right)$ with $\operatorname{corr}\left(\varepsilon_{i}, \mu_{i}\right)=\rho$, we can reformulate equation (3) as:

$$
\begin{gathered}
E\left(\Delta \ln S_{i, t} \mid S_{i, t-1}, \chi_{i, t}=1\right)=\beta_{0}+\beta_{1} \ln S_{i, t-1}+\rho \sigma_{\varepsilon} \lambda_{i} \\
\text { where } \lambda_{i}=\frac{\phi\left(\alpha^{\prime} z_{i}\right)}{\Phi\left(\alpha^{\prime} z_{i}\right)} \text { is the inverse of Mills' ratio. }{ }^{10}
\end{gathered}
$$

The two-step estimation procedure requires one to estimate the probit selection model first ${ }^{11}$. Once $\lambda_{i}$ has been obtained for each observation, the main equation (5) is estimated, augmenting the observations with the Mills' ratio inverse, to obtain an additional parameter estimate $\beta_{M}=\hat{\rho} \hat{\sigma}_{\varepsilon}$ from which we can simply recover the two-step estimate of $\hat{\rho}=\frac{\beta_{M}}{\hat{\sigma}_{\varepsilon}}$. We used Maximum 
Likelihood estimation $^{12}$ with robust standard errors since heteroskedasticity has been detected in all the specifications (as reported in the following tables).

Consistently with most previous studies, robustness checks have been developed augmenting the main equation with the age variable, squared and interaction terms. The same specifications were tested over the entire period (1987-1994) and year by year (seven separate estimates).

Chesher's logarithmic specification of Gibrat's Law only considers surviving firms and calls for a sample selection approach. A possible alternative methodology is to test directly a growth equation and consider exit as a $-100 \%$ rate of change (see Evans 1987a and 1987b) ${ }^{13}$ :

$$
G_{i, t}=\beta_{0}+\beta_{1} \ln S_{i, t-1}+\varepsilon_{i, t}
$$

where: $G_{i, t}=\left(S_{i, t}-S_{i, t-1}\right) / S_{i, t-1} \quad$ with: $S_{i, t}=0$ in case of exit

In this alternative specification if $\beta_{1}=0$, Gibrat's Law holds; if $\beta_{1}<0$, smaller firms grow at a higher rate than their larger counterparts, while the opposite is the case if $\beta_{1}>0$. Robustness checks taking into account the possible role of age, squared and interaction variables were implemented in this specification as well.

\section{Results}

Tables 2 and following ones present the regression results over the entire period examined (19871994) and year by year. The model specification is given in the headline, while coefficient estimates are presented together with robust standard errors and level of statistical significance 
(*=90\%; **=95\%; ***=99\%). Gibrat's coefficients $\beta 1$ are central to our analysis, and the validity of the Law is tested through their estimates.

In Tables 2, 3 and 4 coefficient estimates from the sample selection model are presented, and overall diagnostic tests are reported, including the estimate of the correlation between the residuals of the main and the selection equation $(\rho)$ with the related significance level of the corresponding Likelihood Ratio test ${ }^{14}$. As can be seen from all the three tables, the need for the sample selection model has been confirmed, especially in the first years of the period examined. Next, estimates of $\lambda$, Wald tests for the overall validity of the model, and White heteroskedasticity tests are reported. Finally, the reader can follow the market selection process by looking at the number of observations, the decrease in these marking the incidence of firms' failures.

\section{- Insert tables 2, 3 and 4 here -}

Examination of table 2 prompts two basic considerations:

1) Consistently with previous studies (see Section 2), Gibrat's Law is rejected ex ante over the entire period 1987-94, with a $\beta_{1}=-0.153$ significantly different from 0 at the $99 \%$ level of confidence; smaller firms seem to grow faster than their larger counterparts. Moreover, an initial larger size improves the likelihood of survival, although in a non-linear fashion.

2) $\beta_{1}$ is not only smaller - in absolute terms - in the yearly estimates (this being simply a consequence of the expected close similarity in size in two adjacent years), but increases over time (although not monotonically) and is not statistically different from 0 in the last period ${ }^{15}$. Overall, some evidence of an ex post convergence to Gibrat-like behavior emerges.

Some further considerations arise when one looks at the more comprehensive Table 3, which takes the age variable into account. 
3) Consistently with previous studies, the inverse relationship between age and growth $\left(\beta_{2}\right)$ is confirmed over the entire period, yet age seems to lose its role in the second sub-period (19901994).

4) As in the previous estimates, Gibrat's Law is rejected in general, but convergence towards the validity of the Law occurs through time. In this table, $\beta 1$ is not statistically significant from 199091 onwards $^{16}$; the departure from Gibrat's Law is confined to the first three years, when the population of firms is still strongly characterized by the presence of smaller and younger firms exhibiting a higher propensity to grow. However, in the long run, size and age diminish in significance and ex post the steady-state sub-population of surviving firms displays a Gibrat-like behavior. Indeed, it is plausible to conclude that the resulting 1,933 most efficient firms show - and will probably continue to show in the subsequent periods for which data are not available - growth patterns consistent with the Law of Proportionate Effect.

5) The findings discussed in the previous point are further confirmed by the results reported in Table 4, where additional robustness checks have been inserted (squared and interaction terms).

Turning our attention to the alternative specification (6), results are reported in the following Tables 5, 6 and 7.

\section{- Insert tables 5, 6 and 7 here -}

6) As in Chesher's specification, Gibrat's Law is rejected over the entire 1987-94 period ( $\beta 1$ $=-0.202$ at a $99 \%$ level of statistical significance). However, in this case too, convergence towards the Law can be detected through time: $\beta 1$ turns out to be not significant from 1990-91 onwards.

7) This basic result is confirmed in Tables 7 and 8, where the complementary role of age and further controls are taken into account. Finally, as in the previous estimates, age loses its significance in the last years of the examined period. 


\section{Conclusions}

The main finding of this study on the Italian radio, TV \& communication equipment industry over the period 1987-94 is that the rejection of Gibrat's Law, common to most previous empirical research and also found here, should be reconsidered from a different perspective once market selection is properly taken into account.

Indeed, whilst we find that Gibrat's Law must be rejected ex ante, convergence towards Gibrat-like behavior through time is detected ex post; in other words, the reshaped and shrunken population of surviving and therefore most efficient firms exhibits within itself patterns of growth that are consistent with Gibrat’s Law.

This evidence entails that through time, learning (either passive or active) and market selection originate a "core" of surviving firms which tends to behave according to the Law of Proportionate Effect, especially when the sector is subjected to some sort of shakeout as in our example. This evidence reconciles the diverging results emerging from the previous empirical literature analyzed in Section 2 and is consistent with the recent theoretical models of market selection also discussed in that section. If these results are confirmed by future research, Gibrat's Law can be regarded as a way to describe what occurs in the long run, once learning and market selection have fully played their roles. From this point of view, Gibrat's Law remains a useful tool for theoretical reasoning. 


\section{References}

Audretsch, D. B., E. Santarelli and M. Vivarelli, 1999, "Start-up Size and Industrial Dynamics: Some Evidence from Italian Manufacturing”, International Journal of Industrial Organization, 17, 965-983.

Bartelsman, E., S. Scarpetta and F. Schivardi, 2005, "Comparative Analysis of Firm Demographics and Survival: Evidence from Micro-level Sources in OECD Countries”, Industrial and Corporate Change, 14, 365-391.

Cabral, L., 1995, "Sunk Costs, Firm Size and Firm Growth”, Journal of Industrial Economics, 43, 161-172.

Calvo, J.L., 2006, “Testing Gibrat's Law for Small, Young and Innovating Firms”, Small Business Economics, 26, 117-123.

Carree, M.A., 2002, "Technological Progress, Structural Change and Productivity Growth: A Comment”, Structural Change and Economic Dynamics, 14, 109-155.

Caves, R. E, 1998, "Industrial Organization and New Findings on the Turnover and Mobility of Firms”, Journal of Economic Literature, 36, 1947-1982.

Chesher, A., 1979, “Testing the Law of Proportionate Effect”, Journal of Industrial Economics, 27, 403-411.

CNEL, 2001, “Competitività e sostenibilità dei modelli di innovazione del sistema produttivo italiano", Rome, Hermes Lab for CNEL.

Dunne, P. and A. Hughes, 1994, "Age, Size, Growth and Survival: UK Companies in the 1980s”, Journal of Industrial Economics, 42, 115-140.

Dunne, T., M. J. Roberts and L. Samuelson, 1988, "Patterns of Firm Entry and Exit in U.S. Manufacturing Industries”, Rand Journal of Economics, 19, 495-515.

Dunne, T., M. J. Roberts and L. Samuelson, 1989, "The Growth and Failure of US Manufacturing Plants”, Quarterly Journal of Economics, 104, 671-698.

Endres, A.M. and Woods, C.R., 2006, "Modern Theories of Entrepreneurial Behavior: A Comparison and Appraisal”, Small Business Economics, 26, 189-202.

Ericson, R. and A. Pakes, 1995, "Markov-Perfect Industry Dynamics: a Framework for Empirical Work", Review of Economic Studies, 62, 53-82.

Evans, D. S., 1987a, Tests of Alternative Theories of Firm Growth", Journal of Political Economy, 95, 657-674.

Evans, D. S., 1987b, “The Relationship Between Firm Growth, Size, and Age: Estimates for 100 Manufacturing Industries”, Journal of Industrial Economics, 35, 567-581.

Foti, A. and M. Vivarelli, 1994, "An Econometric Test of the Self-employment Model: The Case of Italy”, Small Business Economics, 6, 81-93.

Geroski, P., 1995, “What Do We Know About Entry?”, International Journal of Industrial Organization, 13, 421-440.

Gibrat, R., 1931, Les Inegalites Economiques, Paris, Librairie du Recueil Sirey.

Hall, B., 1987, “The Relationship Between Firm Size and Firm Growth in the US Manufacturing Sector", Journal of Industrial Economics, 3, 583-606

Hart, P. E. and N. Oulton, 1996, "Growth and Size of Firms", Economic Journal, 106, 12421252.

Hart, P. E. and S.J. Prais, 1956, "The Analysis of Business Concentration: A Statistical Approach”, Journal of the Royal Statistical Society, 119, series A, 150-191.

Heckman, J. J., 1979, "Sample Selection Bias as a Specification Error”, Econometrica, 47, 153161.

Hymer, S, and P. Pashigian, 1962, "Firm Size and the Rate of Growth”, Journal of Political Economy, 70, 556-569.

Jovanovic, B., 1982, “Selection and Evolution of Industry”, Econometrica, 50, 649-670. 
Kihlstrom, R. E., and J. J. Laffont, 1979, “A General Equilibrium Entrepreneurial Theory of Firm Formation Based on Risk Aversion”, Journal of Political Economy, 87, 719-748.

Klepper, S., and J.H. Miller, 1995, "Entry, Exit, and Shakeouts in the United States in New

Manufactured Products”, International Journal of Industrial Organization, 13, 567-591.

Knight, F., 1921, Risk, Uncertainty and Profit, Boston, Houghton Mifflin

Lotti, F., E. Santarelli and M. Vivarelli, 2001, “The Relationship Between Size and Growth: The Case of Italian Newborn Firms", Applied Economics Letters, 8, 451-454.

Lotti, F., E. Santarelli and M. Vivarelli, 2003, "Does Gibrat's Law Hold Among Young, Small Firms? ”, Journal of Evolutionary Economics, 13, 213-235.

Lotti, F. and. E. Santarelli, 2004, "Industry Dynamics and the Distribution of Firm Sizes: A Non-parametric Approach”, Southern Economic Journal, 70, 443-466.

Lucas, R. E., Jr., 1978, "On the Size Distribution of Business Firms", Bell Journal of Economics, 9, pp. 508-523.

Mansfield, E., 1962, “Entry, Gibrat's Law, Innovation, and the Growth of Firms”, American Economic Review, 52, 1023-1051.

Martins, J.O., S. Scarpetta and D. Pilat, 1996, "Mark-Up Pricing, Market Structure and the Business Cycle”, OECD Economic Studies, 27, 71-105.

McCloughan, P., 1995, "Simulation of Concentration Development from Modified Gibrat Growth-Entry-Exit Processes”, Journal of Industrial Economics, 43, 405-433.

Oxenfeldt, A.R., 1943, New Firms and Free Enterprise: Pre-War and Post-War Aspects, Washington (DC), American Council on Public Affairs.

Pakes, A. and R. Ericson, 1998, "Empirical Implications of Alternative Models of Firm Dynamics”, Journal of Economic Theory, 79, 1-45.

Prais, S.J., 1976, The Evolution of Giant Firms in Britain, London, Cambridge University Press.

Simon, H. A. and C. P. Bonini, 1958, “The Size Distribution of Business Firms”, American Economic Review, 58, 607-617.

Santarelli, E., L. Klomp and A. R. Thurik, 2006, “Gibrat's Law: An Overview of the Empirical Literature”, in E. Santarelli (Ed.), Entrepreneurship, Growth, and Innovation: the Dynamics of Firms and Industries, Springer, New York, 41-73

Steindl, J., 1965, Random Processes and the Growth of Firms: a Study of the Pareto Law, London, Griffin.

Sutton, J., 1997, “Gibrat’s Legacy”, Journal of Economic Literature, 35, 40-59.

Viner, J., 1932, “Cost Curves and Supply Curves”, Zeitschrift für Nationalöconomie, 3, 23-46.

Vivarelli, M., 2004, Are All the Potential Entrepreneurs So Good?, Small Business Economics, 23, 41-49. 
Table 1 : Number of active firms, average size and standard deviation.

\begin{tabular}{cccc} 
Year & Number of active firms & $\begin{array}{c}\text { Average size of } \\
\text { surviving firms }\end{array}$ & Standard deviation \\
1987 & 3285 & 35.99 & 285.14 \\
1988 & 3216 & 37.07 & 277.46 \\
1989 & 2893 & 44.34 & 343.17 \\
1990 & 2743 & 44.89 & 337.04 \\
1991 & 2564 & 46.10 & 336.10 \\
1992 & 2347 & 45.11 & 368.56 \\
1993 & 2149 & 46.31 & 346.37 \\
1994 & 1933 & 45.83 & 378.60 \\
\hline
\end{tabular}


Table 2: Sample selection model.

Main equation: $\Delta \ln S_{i, t}=\beta_{0}+\beta_{1} \ln S_{i, t-1}+\varepsilon_{i, t} \quad$ Selection equation: $\operatorname{Pr}\left(\delta_{i, t}=1\right)=F\left(\ln S_{i, t-1}, \ln S_{i, t-1}{ }^{2}\right.$, const $)$

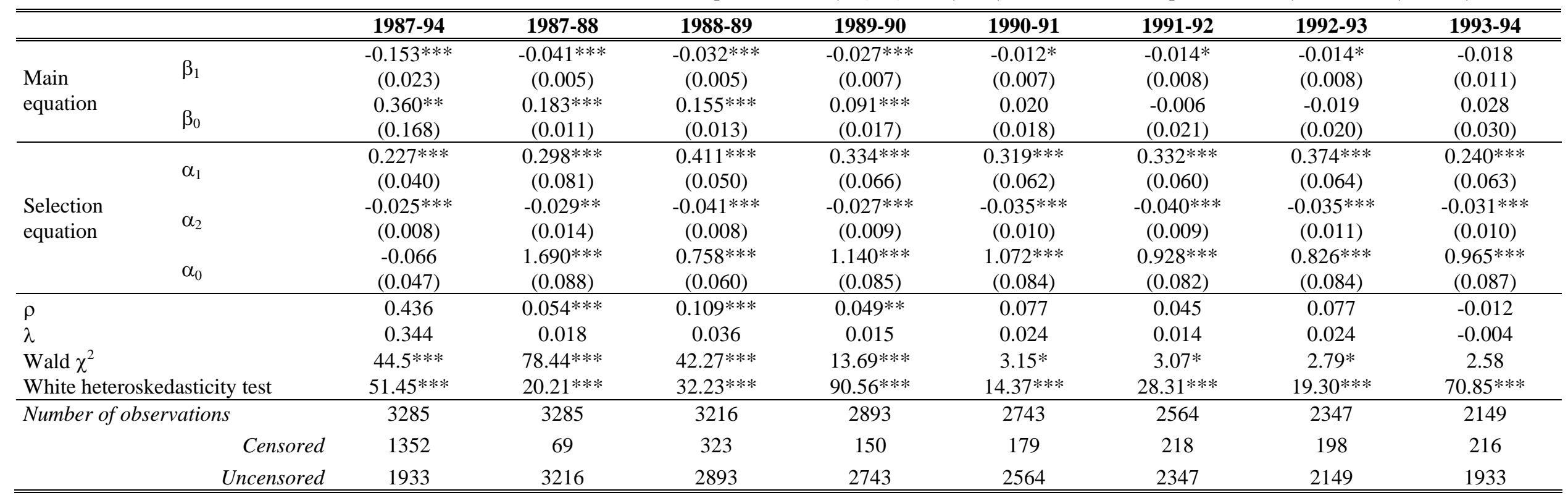

$* * *, * *, *$ mean statistically significant at $1 \%, 5 \%$ and $10 \%$ confidence level, respectively. Robust standard errors in brackets (when White heteroskedasticity test is significant). $\Delta \ln S_{\mathrm{i}, \mathrm{t}}=\ln \mathrm{S}_{\mathrm{i}, \mathrm{t}}-\ln \mathrm{S}_{\mathrm{i}, \mathrm{t}-\mathrm{1}}$. 
Table 3: Sample selection model augmented with age.

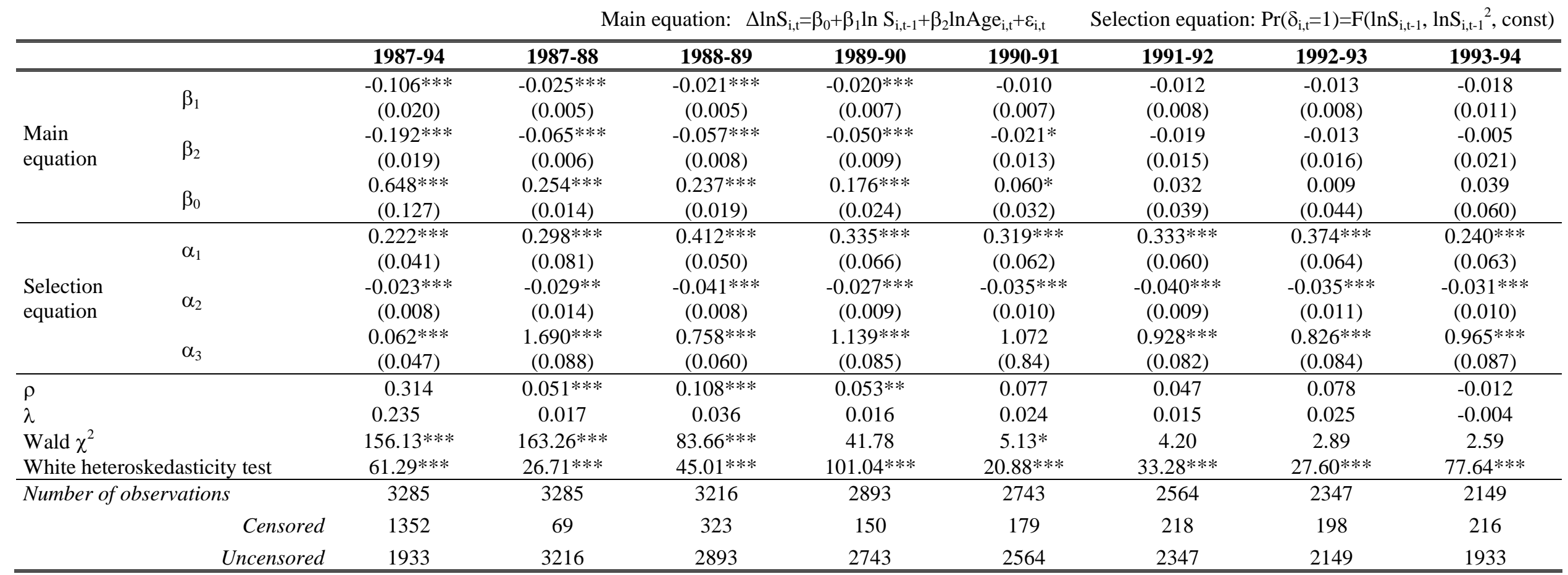

$* * *, * *, *$ mean statistically significant at $1 \%, 5 \%$ and $10 \%$ confidence level, respectively. Robust standard errors in brackets (when White heteroskedasticity test is significant). $\Delta \ln S_{\mathrm{i}, \mathrm{t}}=\ln S_{\mathrm{i}, \mathrm{t}}-\ln \mathrm{S}_{\mathrm{i}, \mathrm{t}-\mathrm{1}}$. 
Table 4: Sample selection model augmented with age, squares and interaction.

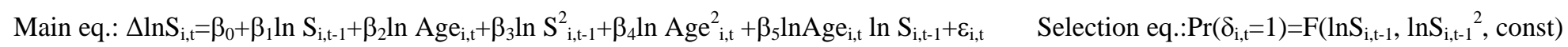

\begin{tabular}{|c|c|c|c|c|c|c|c|c|c|}
\hline & & $1987-94$ & 1987-88 & 1988-89 & $1989-90$ & $1990-91$ & 1991-92 & 1992-93 & 1993-94 \\
\hline \multirow{12}{*}{$\begin{array}{l}\text { Main } \\
\text { equation }\end{array}$} & \multirow{2}{*}{$\beta_{1}$} & $-0.272 * * *$ & $-0.058 * * *$ & $-0.084 * * *$ & $\begin{array}{c}-0.038 \\
\end{array}$ & "-0.019 & -0.004 & -0.001 & $\begin{array}{c}0.050 \\
\end{array}$ \\
\hline & & $(0.048)$ & $(0.011)$ & $(0.015)$ & $(0.031)$ & $(0.027)$ & $(0.043)$ & $(0.041)$ & $(0.077)$ \\
\hline & \multirow{2}{*}{$\beta_{2}$} & $-0.229 * * *$ & $-0.088 * * *$ & $-0.073^{*}$ & -0.075 & -0.023 & -0.188 & 0.070 & -0.007 \\
\hline & & $(0.061)$ & $(0.022)$ & $(0.038)$ & $(0.052)$ & $(0.092)$ & $(0.141)$ & (0.179) & $(0.253)$ \\
\hline & \multirow{2}{*}{$\beta_{3}$} & 0.010 & $0.004 * * *$ & $0.006 * * *$ & 0.000 & 0.002 & 0.002 & 0.001 & 0.000 \\
\hline & & $(0.009)$ & $(0.001)$ & $(0.002)$ & $(0.004)$ & $(0.003)$ & $(0.005)$ & $(0.004)$ & $(0.008)$ \\
\hline & \multirow{2}{*}{$\beta_{4}$} & -0.018 & 0.004 & -0.004 & 0.002 & 0.001 & 0.041 & -0.014 & 0.013 \\
\hline & & $(0.208)$ & $(0.007)$ & $(0.010)$ & $(0.013)$ & $(0.020)$ & $(0.032)$ & $(0.035)$ & $(0.053)$ \\
\hline & \multirow{2}{*}{$\beta_{5}$} & $0.052 * * *$ & 0.007 & $0.015^{* *}$ & 0.007 & -0.002 & -0.009 & -0.007 & -0.027 \\
\hline & & $(0.017)$ & $(0.005)$ & $(0.006)$ & $(0.008)$ & $(0.011)$ & $(0.012)$ & $(0.018)$ & $(0.019)$ \\
\hline & \multirow{2}{*}{$\beta_{0}$} & $0.986 * * *$ & $0.294 * * *$ & $0.320 * * *$ & $0.220 * * *$ & 0.073 & 0.211 & -0.102 & -0.043 \\
\hline & & $(0.68)$ & $(0.022)$ & $(0.040)$ & $(0.064)$ & $(0.103)$ & $(0.165)$ & $(0.226)$ & $(0.320)$ \\
\hline \multirow{6}{*}{$\begin{array}{l}\text { Selection } \\
\text { equation }\end{array}$} & \multirow[b]{2}{*}{$\alpha_{1}$} & $0.206 * * *$ & $0.294 * * *$ & $0.402 * * *$ & $0.334^{* * *}$ & $0.318^{* * *}$ & $0.332 * * *$ & $0.374 * * *$ & $0.240 * * *$ \\
\hline & & (0.038) & $(0.081)$ & $(0.050)$ & $(0.066)$ & $(0.062)$ & $(0.060)$ & $(0.064)$ & $(0.063)$ \\
\hline & \multirow[b]{2}{*}{$\alpha_{2}$} & $-0.020 * * *$ & $-0.029 * *$ & $-0.039 * * *$ & $-0.027 * * *$ & $-0.035^{* * *}$ & $-0.040 * * *$ & $-0.034 * * *$ & $-0.031 * * *$ \\
\hline & & $(0.007)$ & $(0.014)$ & $(0.008)$ & (0.009) & $(0.010)$ & $(0.009)$ & $(0.011)$ & $(0.010)$ \\
\hline & \multirow[b]{2}{*}{$\alpha_{3}$} & 0.049 & $1.693^{* * *}$ & $0.765 * * *$ & $1.140 * * *$ & $1.074 * * *$ & $0.929 * * *$ & $0.826 * * *$ & $0.965 * * *$ \\
\hline & & $(0.046)$ & $(0.088)$ & $(0.060)$ & $(0.085)$ & $(0.084)$ & $(0.082)$ & $(0.084)$ & $(0.087)$ \\
\hline \multicolumn{2}{|l|}{$\rho$} & $0.037 * * *$ & $0.016^{* * *}$ & $0.018 * * *$ & $0.045^{* * *}$ & 0.046 & $0.027 *$ & $0.074 *$ & 0.005 \\
\hline \multicolumn{2}{|l|}{$\lambda$} & 0.27 & 0.005 & 0.006 & 0.013 & 0.014 & 0.009 & 0.023 & 0.002 \\
\hline \multicolumn{2}{|l|}{ Wald $\chi^{2}$} & $296.47 * * *$ & $177.96 * * *$ & $112.64 * * *$ & 59.67 & $10.04 *$ & $16.06 * * *$ & 5.22 & $11.59 * *$ \\
\hline \multicolumn{2}{|c|}{ White heteroskedasticity test } & $111.09 * * *$ & $46.92 * * *$ & $54.10^{* * *}$ & $192.51^{* * *}$ & $52.45^{* * *}$ & $117.29 * * *$ & $59.88 * * *$ & $251.42 * * *$ \\
\hline \multicolumn{2}{|c|}{ Number of observations } & 3285 & 3285 & 3216 & 2893 & 2743 & 2564 & 2347 & 2149 \\
\hline & Censored & 1352 & 69 & 323 & 150 & 179 & 218 & 198 & 216 \\
\hline & Uncensored & 1933 & 3216 & 2893 & 2743 & 2564 & 2347 & 2149 & 1933 \\
\hline
\end{tabular}

$* * *, * *, *$ mean statistically significant at $1 \%, 5 \%$ and $10 \%$ confidence level, respectively. Robust standard errors in brackets (when White heteroskedasticity test is significant). $\Delta \ln S_{\mathrm{i}, \mathrm{t}}=\ln \mathrm{S}_{\mathrm{i}, \mathrm{t}}-\ln \mathrm{S}_{\mathrm{i}, \mathrm{t}-1}$. 
Table 5: Growth model.

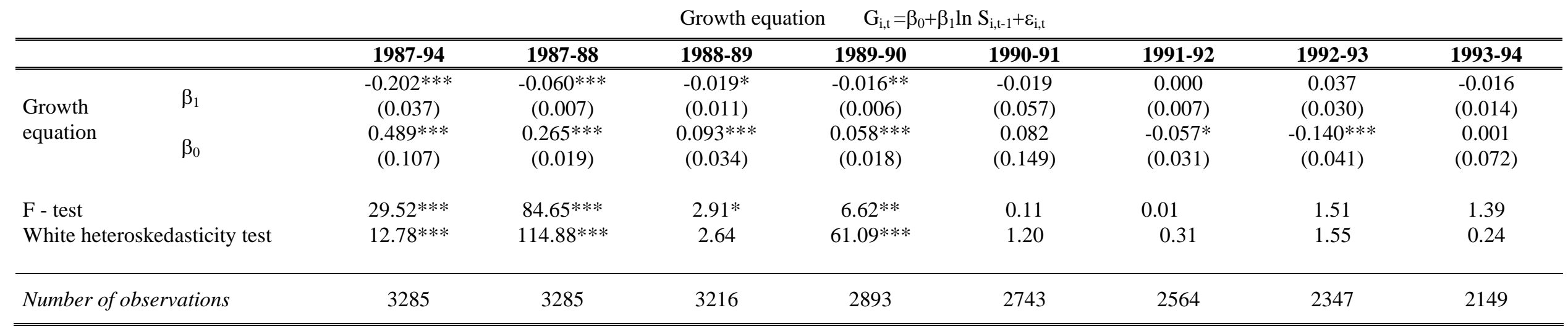

$* * *, * *, *$ mean statistically significant at $1 \%, 5 \%$ and $10 \%$ confidence level, respectively. Robust standard errors in brackets (when White heteroskedasticity test is significant). Growth rate is computed as $\mathrm{G}_{\mathrm{i}, \mathrm{t}}=\left(\mathrm{S}_{\mathrm{i}, \mathrm{t}}-\mathrm{S}_{\mathrm{i}, \mathrm{t}-1}\right) / \mathrm{S}_{\mathrm{i}, \mathrm{t}-1}$ 
Table 6: Growth model augmented with age.

Growth equation $\quad \mathrm{G}_{\mathrm{i}, \mathrm{t}}=\beta_{0}+\beta_{1} \ln \mathrm{S}_{\mathrm{i},-\mathrm{-}-1}+\beta_{2} \ln A g \mathrm{ge}_{\mathrm{i}, \mathrm{t}}+\varepsilon_{\mathrm{i}, \mathrm{t}}$

\begin{tabular}{|c|c|c|c|c|c|c|c|c|}
\hline & $1987-94$ & 1987-88 & 1988-89 & $1989-90$ & $1990-91$ & 1991-92 & 1992-93 & 1993-94 \\
\hline \multirow{4}{*}{$\begin{array}{l}\text { Growth } \\
\text { equation }\end{array}$} & $\begin{array}{c}-0.149 * * * \\
(0.043)\end{array}$ & $\begin{array}{c}-0.038^{* * *} \\
(0.006)\end{array}$ & $\begin{array}{c}-0.004 \\
(0.010)\end{array}$ & $\begin{array}{l}-0.008 \\
(0.006)\end{array}$ & $\begin{array}{c}-0.041 \\
(0.062)\end{array}$ & $\begin{array}{c}-0.007 \\
(0.012)\end{array}$ & $\begin{array}{c}0.029 \\
(0.020)\end{array}$ & $\begin{array}{c}-0.034 \\
(0.030)\end{array}$ \\
\hline & $-0.210^{* * *}$ & $-0.088^{* * *}$ & $-0.081^{* * *}$ & $-0.055^{* * *}$ & 0.192 & -0.077 & 0.091 & 0.225 \\
\hline & $0.717 * * *$ & $0.360 * * *$ & $0.208^{* * *}$ & $0.152 * * *$ & -0.284 & $\begin{array}{l}(0.110) \\
-0.215\end{array}$ & $\begin{array}{l}(0.122) \\
-0.339\end{array}$ & $\begin{array}{c}(0.234) \\
-0.520\end{array}$ \\
\hline & $(0.112)$ & $(0.024)$ & $(0.050)$ & $(0.030)$ & $(0.250)$ & $(0.203)$ & $(0.302)$ & $(0.476)$ \\
\hline \multirow{2}{*}{$\begin{array}{l}\text { F - test } \\
\text { White heteroskedasticity test }\end{array}$} & $28.67 * * *$ & $67.85 * * *$ & $12.56^{* * *}$ & $11.93 * * *$ & 0.84 & 0.25 & 2.04 & 0.69 \\
\hline & $13.42 * *$ & $141.78^{* * *}$ & $4.26^{* * *}$ & $67.30 * * *$ & 7.95 & $10.64 *$ & $10.89 *$ & $13.27 * *$ \\
\hline Number of observations & 3285 & 3285 & 3216 & 2893 & 2743 & 2564 & 2347 & 2149 \\
\hline
\end{tabular}

$* * *, * *, *$ mean statistically significant at $1 \%, 5 \%$ and $10 \%$ confidence level, respectively. Robust standard errors in brackets (when White heteroskedasticity test is significant). Growth rate is computed as $\mathrm{G}_{\mathrm{i}, \mathrm{t}}=\left(\mathrm{S}_{\mathrm{i}, \mathrm{t}}-\mathrm{S}_{\mathrm{i}, \mathrm{t}-1}\right) / \mathrm{S}_{\mathrm{i}, \mathrm{t}-1}$ 
Table 7: Growth model augmented with age, squares and interaction.

Growth eq. $\mathrm{G}_{\mathrm{i}, \mathrm{t}}=\beta_{0}+\beta_{1} \ln \mathrm{S}_{\mathrm{i}, \mathrm{t}-1}+\beta_{2} \ln \mathrm{Age}_{\mathrm{i}, \mathrm{t}}+\beta_{3} \ln \mathrm{S}_{\mathrm{i}, \mathrm{t}-\mathrm{1}}^{2}+\beta_{4} \ln \operatorname{Age}_{\mathrm{i}, \mathrm{t}}^{2}+\beta_{5} \ln \operatorname{Age}_{\mathrm{i}, \mathrm{t}} \ln \mathrm{S}_{\mathrm{i}, \mathrm{t}-1}+\varepsilon_{\mathrm{i}, \mathrm{t}}$

\begin{tabular}{|c|c|c|c|c|c|c|c|c|c|}
\hline & & $1987-94$ & $1987-88$ & 1988-89 & $1989-90$ & 1990-91 & 1991-92 & 1992-93 & 1993-94 \\
\hline \multirow{7}{*}{$\begin{array}{l}\text { Growth } \\
\text { equation }\end{array}$} & $\beta_{1}$ & $\begin{array}{c}-0.467 * * * \\
(0.101)\end{array}$ & $\begin{array}{c}-0.102^{* * *} \\
(0.021)\end{array}$ & $\begin{array}{l}-0.058^{*} \\
(0.032)\end{array}$ & $\begin{array}{c}-0.052 * * \\
(0.025)\end{array}$ & $\begin{array}{c}-0.054 \\
(0.047)\end{array}$ & $\begin{array}{c}0.049 \\
(0.089)\end{array}$ & $\begin{array}{c}-0.055 \\
(0.102)\end{array}$ & $\begin{array}{c}0.221 \\
(0.291)\end{array}$ \\
\hline & $\beta_{2}$ & $\begin{array}{c}-0.332^{* *} \\
(0.154)\end{array}$ & $\begin{array}{c}-0.138 * * * \\
(0.036)\end{array}$ & $\begin{array}{l}-0.119 * \\
(0.064)\end{array}$ & $\begin{array}{c}-0.074 \\
(0.075)\end{array}$ & $\begin{array}{c}-0.808 \\
(1.052)\end{array}$ & $\begin{array}{l}-1.135 \\
(1.133)\end{array}$ & $\begin{array}{l}-1.162 \\
(1.520)\end{array}$ & $\begin{array}{c}-2.886 \\
(3.252)\end{array}$ \\
\hline & $\beta_{3}$ & $\begin{array}{r}0.023 \\
(0.019)\end{array}$ & $\begin{array}{l}0.007 * * * \\
(0.002)\end{array}$ & $\begin{array}{r}-0.001 \\
(0.003)\end{array}$ & $\begin{array}{r}0.001 \\
(0.003)\end{array}$ & $\begin{array}{r}0.014 \\
(0.035)\end{array}$ & $\begin{array}{c}-0.008 \\
(0.007)\end{array}$ & $\begin{array}{r}-0.011 \\
(0.012)\end{array}$ & $\begin{array}{r}-0.001 \\
(0.005)\end{array}$ \\
\hline & $\beta_{4}$ & $\begin{array}{r}-0.022 \\
(0.049)\end{array}$ & $\begin{array}{r}0.010 \\
(0.010)\end{array}$ & $\begin{array}{r}-0.005 \\
(0.019)\end{array}$ & $\begin{array}{c}-0.005 \\
(0.018)\end{array}$ & $\begin{array}{r}0.248 \\
(0.244)\end{array}$ & $\begin{array}{r}0.268 \\
(0.283)\end{array}$ & $\begin{array}{r}0.233 \\
(0.307)\end{array}$ & $\begin{array}{r}0.661 \\
(0.745)\end{array}$ \\
\hline & \multirow{2}{*}{$\beta_{5}$} & $0.110 *$ & $0.015 *$ & $0.030 *$ & $0.017 *$ & $\begin{array}{r}(0.244) \\
-0.031\end{array}$ & $\begin{array}{r}(0.283) \\
-0.008\end{array}$ & $\begin{array}{r}(0.30 /) \\
0.055\end{array}$ & $\begin{array}{r}(0.145) \\
-0.099\end{array}$ \\
\hline & & $(0.051)$ & $(0.008)$ & $(0.013)$ & $(0.010)$ & $(0.122)$ & $(0.030)$ & $(0.068)$ & $(0.123)$ \\
\hline & $\beta_{0}$ & $\begin{array}{c}1.081^{* * *} \\
(0.184)\end{array}$ & $\begin{array}{c}0.440 * * * \\
(0.042)\end{array}$ & $\begin{array}{c}0.297 * * * \\
(0.086)\end{array}$ & $\begin{array}{c}0.219 * * \\
(0.086)\end{array}$ & $\begin{array}{c}0.735 \\
(1.015)\end{array}$ & $\begin{array}{c}1.059 \\
(1.068)\end{array}$ & $\begin{array}{c}1.239 \\
(1.771)\end{array}$ & $\begin{array}{c}3.021 \\
(3.465)\end{array}$ \\
\hline \multirow{2}{*}{\multicolumn{2}{|c|}{$\begin{array}{l}\text { F - test } \\
\text { White heteroskedasticity test }\end{array}$}} & $13.03 * * *$ & $41.06^{* * *}$ & $5.55 * * *$ & $5.13 * * *$ & 0.95 & 0.67 & 0.88 & 0.41 \\
\hline & & $21.98^{*}$ & $169.52 * * *$ & 6.55 & $84.01 * * *$ & $24.52 * *$ & $21.68 *$ & $25.16^{*}$ & $25.24 *$ \\
\hline \multicolumn{2}{|c|}{ Number of observations } & 3285 & 3285 & 3216 & 2893 & 2743 & 2564 & 2347 & 2149 \\
\hline
\end{tabular}

$* * *, * *, *$ mean statistically significant at $1 \%, 5 \%$ and $10 \%$ confidence level, respectively. Robust standard errors in brackets (when White heteroskedasticity test is significant). Growth rate is computed as $\mathrm{G}_{\mathrm{i}, \mathrm{t}}=\left(\mathrm{S}_{\mathrm{i}, \mathrm{t}}-\mathrm{S}_{\mathrm{i}, \mathrm{t}-\mathrm{1}}\right) / \mathrm{S}_{\mathrm{i}, \mathrm{t}-1}$ 


\footnotetext{
1 These methodological issues will be treated in detail in Section 3.

${ }^{2}$ Jovanovic's model can be seen as a modern version of a theory of entrepreneurship which depicts new firm founders as risk-taking agents (see Knight, 1924; Oxenfeldt, 1943; cf. also Kihlstrom and Laffont, 1979; Endres and Woods, 2006).

${ }^{3}$ To our knowledge, this is the first attempt to test Gibrat's Law through time in search of a possible convergence to the Law; the only exceptions being previous works by the authors of the present paper (Lotti, Santarelli and Vivarelli, 2001 and 2003). However, in those papers we dealt solely with newborn firms across (almost) the entire spectrum of Italian industrial sectors. On the peculiarities which characterize the entry and post-entry performance of new Italian manufacturing firms, see also Foti and Vivarelli, 1994 and Vivarelli, 2004.

${ }^{4}$ Focusing on a sole industry permits the wiping out of significant intersectoral differences in the patterns of firms' entry, exit and growth (see Dunne, Roberts and Samuelson, 1988).

${ }^{5}$ All private Italian firms are obliged to pay national security contributions for their employees to INPS. Consequently, the registration of a new firm as "active" signals an entry into the market, while the cancellation of a firm denotes an exit from it (this happens when a firm finally stops paying national security contributions). For administrative reasons - delays in payment, for instance, or uncertainty about the actual status of the firm - cancellation may sometimes be preceded by a period during which the firm is "suspended". The present paper considers these suspended firms as exiting from the market at the moment of their transition from the status of "active" to that of "suspended", while firms which have halted operations only temporarily during the follow-up period, and which were "active" in January 1994, have been treated as survivors.

${ }^{6}$ Already around the mid-1990s the examined sector had become one of the most R\&D-intensive in Italy, accounting for about one fourth of total R\&D expenditures in the country (CNEL, 2001).

${ }^{7}$ We thank one of the referees for this useful interpretation. As also shown by previous studies (e.g. Bartelsman et al., 2005), industries characterized by rapid technological change and market experimentation are more likely to exhibit greater firm churning.

${ }^{8}$ This view is shared by industry insiders and experts; in addition, the overall Italian macroeconomic recession in the early ' 90 s made the examined shakeout even more remarkable.

${ }^{9}$ Following a random walk (with drift) stochastic process.

${ }^{10}$ We use $\Phi$ to denote the cumulative density function of the Normal distribution and $\varnothing$ to denote its density function.

${ }^{11}$ Squared size has been inserted in the selection equation to check for possible non linearities in the relationship between initial size and survival.

${ }^{12}$ Since a two-step Heckman's (1979) estimator may be inefficient and biased for small samples.

${ }^{13}$ The sample selection approach treats exit as being heterogeneous as compared with a negative rate of change in size; instead, the growth approach considers exit as a growth of minus $100 \%$. Whether exit should be considered either as a discontinuity or as something comparable with decline in size is a disputable issue. The cautious approach adopted here is that of developing both approaches and seeing whether empirical results are consistent. We thank one of the referees for suggesting the implementation of the second methodology.

${ }^{14}$ The test statistic is $L R=2\left(\log L_{U}-\log L_{R}\right)$, where $\log L_{U}$ and $\log L_{R}$ are the log-likelihoods for the unrestricted and restricted versions of the model, that is distributed as a $\chi^{2}$ statistic with 1 degree of freedom under the null hypothesis that the restriction $\rho=0$ is valid.

${ }^{15}$ There is an initial drop in the significance of the coefficient in the fourth year (from $99 \%$ to $90 \%$ level of confidence) and then full loss of significance in the last year.

${ }^{16}$ While it was only barely significant in 90/91, 91/92 and 92/93 in the previous table; however, by looking at the values of both coefficients and standard errors, the reader can easily see that although they cross the $90 \%$ threshold of statistical significance, outcomes from the two tables are fairly similar.
} 